\title{
The Influence of the Sprint Training Method Towards SSB Player Speed
}

\author{
Yanuar Kiram $^{1 *}$ and Al Mukhlis ${ }^{2}$ \\ ${ }^{1,2}$ Dep. of Coaching, Faculty of Sport Science, Padang State University, Padang, Indonesia \\ *Corresponding author. Email: yanuarkiram@fik.unp.ac.id
}

\begin{abstract}
The problem in this study is the low achievement obtained by the SSB Tunas Harapan player, X Koto Subdistrict, Tanah Datar District. The purpose of this study was to determine whether there is an influence of the sprint training method on the running speed of the SSB Player Tunas Harapan, X Koto District, Tanah Datar District. This type of research is quasi-experimental. The population in this study were all SSB Tunas Harapan players, X Koto sub-district, Tanah Datar District, totaling 70 players. The sampling technique in this study used a purposive sampling technique, so the number of samples in this study were 20 athletes. The research instrument was to measure the running speed of 30 meters. The analysis technique in this study is to use the t test. Based on the results of research and hypothesis testing, it can be concluded that there is a significant effect of the form of sprint training on the running speed of SSB football players Tunas Harapan, X Koto District, Tanah Datar Regency, with a tcount of 5.02 while a table of 1.73 with a standard significant $\alpha=0.05$ and $n-1=19$, then tcount $>$ t table (5.02>1.73). With an average pre test of 5.31 and an increase in the average post test speed time to 5.28 , an increase of 0.3 seconds.
\end{abstract}

Keywords: Sprint Training Exercise, Running Speed

\section{INTRODUCTION}

One of the development sectors which is being actively carried out at present is development in the field of sports. Because through sports it is hoped that the next generation will have character, personality, discipline, cooperation and a sense of responsibility within each individual. Through sports can also be used as a means to strengthen the unity and integrity of the nation, and can also uphold the good name, dignity and dignity of the nation both at the lowest level to the highest. This is in accordance with the Republic of Indonesia Law No. 3/2005 concerning the National Sports System, article 4 on the basis and functions and objectives of sport, namely:"National sports aims to maintain and improve health and fitness, achievements, human qualities, instill moral values and noble morals, sportsmanship, discipline, strengthen and foster national unity, strengthen national resilience, and enhance national dignity, dignity, and honor."

Based on the above quotation, it is clear that one of the goals of national sports is to improve performance, especially achievement in the field of sports. Achievement in sports is not an easy job, it takes maximum effort to achieve these achievements.SMA
Negeri 1 Lintau Buo Utara, Tanah Datar District, which conducts volleyball sports through extracurricular activities, this activity is carried out outside of the subject hours, with two face-to-face sessions with training schedules already programmed by the trainer.

In volleyball games, players must be able to do volleyball game techniques that are supported by good physical conditions. To be able to perform various techniques of playing volleyball properly requires excellent physical conditions. In the volleyball game it takes various elements of physical conditions, such as: strength, endurance, explosive power, speed, flexibility, agility, coordination, balance, accuracy and reaction. All components are needed to support game activities such as: smash, blocking, passing, defend, service.

Based on the results of interviews that researchers have conducted with the volleyball trainers of SMA Negeri 1 Lintau Buo Utara, Tanah Datar Regency, Mr. Aristiady and Mr. Agustiar said the performance of the volleyball performance at SMA Negeri 1 Lintau Buo Utara Tanah Datar District was quite good. Some of the provincial and district championship achievements that have been obtained by volleyball players in SMA Negeri 1 Lintau Buo Utara, 
Tanah Datar District, namely at the 2014 Provincial Polytechnic Volleyball event won 1st place, the 2015 provincial Gebyar volleyball event won second place, the Dandim Cup volleyball event at the provincial level The regency won 2016 in the second place, and the 2018 SMANSA Pantai Cermin volleyball event in the province level won in the third place. The achievements obtained by the North Sumatra 1 Lintau Buo High School volleyball player are quite good, but researchers see a decline from the top achievements obtained by the North Sumatra 1 Lintau Buo North High School volleyball player each year. Many factors can affect achievement, such as: physical condition, technical ability, tactics, mental, facilities and infrastructure and training programs, but the volleyball players at SMAN 1 Lintau Buo Utara are not yet known which factors play a role. However, based on the observations of the writer of volleyball players at SMA Negeri 1 Lintau Buo Utara, this is assumed to have a good physical condition.

Based on the description above, there are many factors that affect the performance of volleyball sports in SMA Negeri 1 Lintau Buo Utara Tanah Datar district, so on this occasion the authors are interested in conducting a study of the Physical Conditions of volleyball players namely leg muscle explosive power, arm muscle explosive power, agility, flexibility, aerobic endurance and eye-hand coordination.

\section{RESEARCH METHODS}

This research is a type of descriptive research. According to Arikunto (2010) that: "Descriptive research is research that does not intend to test certain hypotheses but only describes what they are about a variable, symptom or condition". Referring to the opinion, this study will reveal the actual data about the level of physical condition of volleyball players in SMA Negeri 1 Lintau Buo Utara Tanah Datar District which includes, leg muscle explosive power, arm muscle explosive power, agility, flexibility, aerobic endurance, and coordination hand-eye.

This research was conducted at SMA Negeri 1 Lintau Buo Utara Tanah Datar District in April 2019. The data analysis technique that can be used is to use frequency distribution techniques (descriptive statistics) with percentage calculations, as explained by Sudijono (2012).

\section{RESULTS AND DISCUSSION}

1. Leg muscle explosion power

Based on the results of leg muscle explosive power tests using vertical jumps conducted on 13 male volleyball players in SMA Negeri 1 Lintau Buo Utara Tanah Datar District, the average obtained was 98.1, the standard deviation (standard deviation) was 19.31, the highest value (maximum) 121.9, and the lowest score (minimum) 66.7. It can be concluded that from 13 male volleyball players from SMA Negeri 1 Lintau Buo Utara, none of the players had leg muscle explosive power with excellent classification, 6 people $(46 \%)$ players have good leg muscle explosive power, 3 people (23\%) players who have leg muscle explosive power with medium classification, 3 people $(23 \%)$ players who have leg muscle explosive power with less classification, and 1 person (8\%) player who have leg muscle explosive power with very little classification. Overall, the explosive power of the male volleyball leg muscles of SMA Negeri 1 Lintau Buo Utara is in the "Medium" classification.

While female volleyball players in SMA Negeri 1 Lintau Buo Utara Tanah Datar District totaling 12 people, obtained an average (mean) is 63.1, the standard deviation (standard deviation) is 6.09, the highest value (maximum) 71.6, and the lowest value (minimum) 52.3. It can be concluded that out of 12 female volleyball players in SMA Negeri 1 Lintau Buo Utara, there are no players who have leg muscle explosive power with very good classification, 4 people (33\%) players have good leg muscle explosive power, 5 people (5 people) $42 \%$ ) players who have leg muscle explosive power with moderate classification, 2 people (17\%) players who have leg muscle explosive power with less classification, and 1 person $(8 \%)$ players who have leg muscle explosive power with very less classification. Overall, the explosive power of the limbs of female volleyball players in SMA Negeri 1 Lintau Buo Utara is in the "Medium" classification.

\section{Arm Muscle Power Explosion}

Based on the results of arm muscle explosive tests using One Medicine Ball Put conducted on 13 male volleyball players in SMA Negeri 1 Lintau Buo Utara Tanah Datar District, the average obtained was 7.80, the standard deviation (standard deviation) was 1.32, the highest value (maximum) 10.00, and the lowest value (minimum) 6.30. It can be concluded that of the 13 male volleyball players of SMA Negeri 1 Lintau Buo Utara, 1 person $(8 \%)$ players who have arm muscle explosive 
power with very good classification, 3 people $(23 \%)$ players have good arm muscle explosive power, 4 people $(31 \%)$ players have moderate arm muscle explosive power, 5 people (38\%) players have arm muscle explosive power with less classification, and do not there are players who have arm muscle explosive power with very little classification. Overall, the explosive power of the volleyball forearm in the son of SMA Negeri 1 Lintau Buo Utara is in the "Medium" classification.

While the female volleyball players of SMA Negeri 1 Lintau Buo Utara Tanah Datar District totaling 12 people, obtained an average (mean) of 5.04, the standard deviation (standard deviation) is 0.72 , the highest value (maximum) 6.20, and the lowest value (minimum) 4.10. It can be concluded that out of 12 female volleyball players in SMA Negeri 1 Lintau Buo Utara, 1 person (8\%) players who have explosive arm muscle with excellent classification, 3 people $(25 \%)$ players have good arm muscle explosive power , 3 people $(25 \%)$ players who have arm muscle explosive power with moderate classification, 5 people (42\%) players who have arm muscle explosive power with less classification, and no players who have arm muscle explosive power with very little classification. Overall, the explosive power of the female volleyball forearm arm of SMA Negeri 1 Lintau Buo Utara is in the "Medium" classification.

\section{Agility}

Based on the results of the agility test by using a $4 \times 10$ meter shuttle run test conducted on 13 male volleyball players in SMA Negeri 1 Lintau Buo Utara Tanah Datar District, the average obtained was 11.24, the standard deviation (standard deviation) is 0.80 , the highest value (maximum) is 12.70 , and the lowest value (minimum) is 10.16 . It can be concluded that of the 13 male volleyball players from SMA Negeri 1 Lintau Buo Utara, 11 people $(85 \%)$ players have agility with classification. very well, 2 people $(15 \%)$ players have agility with good classification, no players have agility with medium classification, no players have agility with poor classification, and no players have agility with classification of very low. Overall, the agility of men's volleyball sweaters from SMA Negeri 1 Lintau Buo Utara is in the "Very Good" classification.

While the female volleyball players of SMA Negeri 1 Lintau Buo Utara Tanah Datar District, obtained an average (mean) of 12.55, a standard deviation (standard deviation) of 0.51 , the highest value (maximum) 13.40, and the lowest value (minimum) 11.84. It can be concluded that out of 12 female volleyball players in SMA Negeri 1 Lintau Buo Utara, 5 (42\%) players have excellent agility, 7 people (58\%) have good classification agility, no player has agility with classification while, there are no players with less classification, and no players with less classification. Overall, the agility of female volleyball users in SMA Negeri 1 Lintau Buo Utara is in the "Good" classification.

\section{Determination}

Based on the results of the flexibility test using a flexiometer conducted on 13 male volleyball players of SMA Negeri 1 Lintau Buo Utara Tanah Datar District, the average was 10.77 , the standard deviation was 4.87 , the highest value (maximum) 17 , and the lowest value (minimum) 2. It can be concluded that of the 13 male volleyball players of SMA Negeri 1 Lintau Buo Utara, there are no players who have a very good classification, there are no players who have a good classification, 8 people (62\%) players who have a classification with moderate classification, 2 people (15\%) players who have a classification with less classification, and 3 people (23\%) players who have a classification with a classification that is very poor. Overall, the volleyball performance of male volleyball 1 SMA Negeri 1 Lintau Buo Utara is in the "Less" classification.

While the female volleyball players of SMA Negeri 1 Lintau Buo Utara, Tanah Datar District amounting to 12 people, obtained an average (mean) of 9.63 , standard deviation (standard deviation) of 4.79 , the highest value (maximum) 19.5, and the lowest value (minimum) 4. it can be concluded that out of 12 female volleyball players in SMA Negeri 1 Lintau Buo Utara, there are no players who have a very good classification, 1 person (8\%) players who have a good classification, 3 people (25\%) players who have a classification with moderate classification, 4 people (33\%) players who have a classification with less classification, and 4 people (33\%) players who have a classification with a classification of very few. Overall, the volleyball performance of female volleyball users in SMAN 1 Lintau Buo Utara is in the "Poor" classification.

\section{Aerobic Endurance}

Based on the results of aerobic endurance tests using a bleep test (multistage fitness test) conducted on 
13 male volleyball players from SMA Negeri 1 Lintau Buo Utara Tanah Datar District, the average obtained was 35.8 , the standard deviation (standard deviation) is 5.5, the highest score (maximum) 44.8, and the lowest score (minimum) 28.3. It can be concluded that of the 13 male volleyball players in SMA Negeri 1 Lintau Buo Utara, there are no players who have aerobic endurance with high classification, 2 people $(15 \%)$ players who have aerobic endurance with good classification, 6 people $(46 \%)$ players who have aerobic endurance with enough classification, 5 people $(38 \%)$ players who have aerobic endurance with medium classification, and no player has power aerobic resistance with low classification. Overall, the aerobic endurance of the men's volleyball sweaters from SMA Negeri 1 Lintau Buo Utara is classified as "Sufficient".

While the female volleyball players of SMA Negeri 1 Lintau Buo Utara Tanah Datar District totaling 12 people, obtained an average (mean) of 28.0, standard deviation (standard deviation) of 2.4, the highest value (maximum) 31.4, and the lowest value (minimum) 23.6. It can be concluded that out of 12 female volleyball players in SMA Negeri 1 Lintau Buo Utara, there are no players who have aerobic endurance with high classification, there are no players who have aerobic endurance with good classification, 2 people $(17 \%)$ players who have aerobic endurance with sufficient classification, 9 people $(75 \%)$ players who have aerobic endurance with medium classification, and 1 person (8\%) players who have aerobic endurance with low classification. Overall, the aerobic endurance of female volleyball sweaters in SMA Negeri 1 Lintau Buo Utara is in the "Medium" classification.

\section{Eye-hand Coordination}

Based on the results of eye-hand coordination tests using tennis ball throwing to the wall conducted on 13 male volleyball players of SMA Negeri 1 Lintau Buo Utara Tanah Datar District, the average is 22.23, the standard deviation (standard deviation) is 5.51, the highest score (maximum) 29, and the lowest score (minimum) 12. It can be concluded that of the 13 men's volleyball players of SMA Negeri 1 Lintau Buo Utara, there are no players who have eye-hand coordination with excellent classification, no players who have good hand-eye coordination, 7 people $(54 \%)$ players who have hand-eye coordination with moderate classification, 3 people (23\%) players who have handeye coordination with less classification, and 3 people $(23 \%)$ players who have eye-hand coordination with very little classification. Overall, the eye-hand coordination of volleyball men from SMA Negeri 1 Lintau Buo Utara is in the "Poor" classification.

While the female volleyball players of SMA Negeri 1 Lintau Buo Utara Tanah Datar District totaling 12 people, obtained an average (mean) of 13.92, standard deviation (standard deviation) of 4.70 , the highest value (maximum) 21, and the lowest value (minimum) 7. it can be concluded that out of 12 female volleyball players in SMA Negeri 1 Lintau Buo Utara, there are no players who have good hand-eye coordination with classification, no players have good hand-eye coordination, 2 people $(17 \%)$ players who have hand-eye coordination with moderate classification, 4 people (33\%) players who have eyehand coordination with less classification, and 6 people (50\%) players who have eye-hand coordination with classification very poor.Overall, the eye-hand coordination of female volleyball users of SMA Negeri 1 Lintau Buo Utara is in the classification of "Very Poor".

\section{Discussion}

1. Leg muscle explosion power

In sports Explosive power is an important biomotor component in sports activities because exploitative power will determine how hard people can hit, how hard people can kick, how fast people can run, and how far people can do repulsion. Power concerns the strength and speed of dynamic and explosive muscle contraction and involves the expenditure of maximum muscle strength in the shortest possible time, (Ismaryati, 2006). Leg muscle strength is the maximum contraction force produced by a group of muscles, (Setiawan, 2017).

Based on the opinions of the experts above, it can be concluded that the leg muscle explosive power is the ability of muscles to direct strength in a very short time to provide the best momentum object to the body or objects in an explosive motion that intact to achieve the desired goals. In volleyball games power Leg muscle explosions have the function of creating a maximum jump in making an accurate smash. Smash is the most important element of attack and is a capital to get numbers in volleyball games, therefore smash that is done should be hard and directed, is the main weapon for attack in volleyball. If the explosive power of weak leg muscles does not allow a person to achieve maximum performance (Budhiarta, 2010). Thus it is clear that players who have good leg muscle explosive power certainly can smash well. 
Low leg muscle explosive power will certainly affect the performance of the volleyball players in North Lintau Buo High School 1, because the explosive power of leg muscles is very much needed in doing smashes. Smash is the main capital in getting numbers or points. Therefore, efforts that can be made to increase the leg muscle explosive power are through the process of training, such as bench jumping, squat jumping, long jumping without the start, jumping upright and up and down stairs, with the provision of this exercise it is expected to increase the explosive power of leg muscles of the volleyball players Lintau Buo Utara Public High School.

\section{Arm Muscle Power Explosion}

Arm muscle explosive power is the ability of muscles to direct strength in a very short time to give the object the best momentum in the body or objects in an explosive motion that intact to achieve the desired goal. Explosive power or power is one component of the physical condition that is needed almost in all sports to achieve maximum performance (Juita, et al. 2013). In volleyball sports explosive arm muscle strength is very necessary in doing service, smash, and block. A good arm muscle explosive power determines how strong and hold the arm when doing servie, smash, and when blocking an opponent's attack.

Based on the results of data analysis, it can be concluded that the explosive power of the male and female volleyball player arm muscles in SMA Negeri 1 Lintau Buo Utara is still not optimal, where overall the explosive power of the male and female volleyball player arm muscles is included in the medium classification, where not a few people have explosive power The arm muscles in the classification are very good and good, most of the male and female volleyball players have the explosive power of the arm muscles in the moderate classification, lacking. It can be interpreted that players who have good arm muscle explosive power are likely those players who are accustomed to doing physical activities, as well as they are actively doing sports activities and arm muscle explosive exercises.

Low arm muscle explosive power will certainly affect the performance of volleyball players in SMA Negeri 1 Lintau Buo Utara, therefore efforts are needed to improve it, one of which is through push-up training, pull-up training and throwing catching balls with medicine balls on their own- alone or in pairs. Thus, it can be concluded that the explosive power of the arm volleyball players of SMPN 1 North Lintau North Buoyant is still not optimal, therefore it needs to be improved by doing planned and systematic exercises. 3. Agility

Agility is the ability to quickly change the direction of the body or body parts without distraction and balance. Changing the direction of repetitive body movements such as running back and forth requires alternating contractions in certain muscle groups (Marjana, et al. 2014). This is in accordance with stated by Irawadi (2013: 108) said "agility is the body's ability to move and change direction in the shortest possible time without losing balance".Based on the above opinion it can be concluded that agility is the ability to change the direction and position of the body quickly and precisely at the shortest possible time without losing balance and awareness of body position. As a volleyball player must have an element of agility and without agility the players can not play well and will not develop especially for the purposes of achievement (Ridwan, 2016).

Based on the results of data analysis, it can be concluded that the agility of male and female volleyball players in SMA Negeri 1 Lintau Buo Utara is good, where in the category of sons with excellent classification and women with good classification. Players who have agility in the good category of course they are accustomed to doing physical activities, and they are actively doing sports and training activities to improve agility, such as zig-zag running or shuttle run test. Agility will certainly affect the performance of male and female volleyball players in SMA Negeri 1 Lintau Buo Utara, because in the volleyball game the element of agility is very important to increase winning rate.

\section{Determination}

Determination is the ability of joints and the muscles around them to make maximum movement. Siregar (2015) "Determination is one component of physical condition which is also categorized as a component of basic physical conditions, referred to as a basic physical component because the flexibility stands alone, is not influenced other physical condition components ". In the sport of volleyball the flexibility is very necessary to obtain good results in the mastery of techniques in the game of volleyball. Determination refers to the joint or joint motion and elasticity of the muscles, tendons and ligaments (Hakim, 2012). 
Based on the results of data analysis, it can be concluded that the flexibility of male and female volleyball players in SMA Negeri 1 Lintau Buo Utara is still low, which overall is included in the classification of less, players who have moderate, less, and very less flexibility is caused by these players lacking physical training. Low flexibility will certainly affect the achievements of male and female volleyball players in SMA Negeri 1 Lintau Buo Utara, because in the game of volleyball the element of determination is very important to increase the winning rate. Therefore, flexibility should be increased by providing flexibility exercises such as backing up, kayang, reaching the toe (sit and reach) and various other exercises to increase joint flexibility.

\section{Aerobic Endurance}

Simply put, endurance can be interpreted by the ability to deal with fatigue. But by definition endurance is the ability of the body's organisms to overcome fatigue caused by loading in a relatively long time. Endurance is the ability of the body's organisms to overcome fatigue when doing physical activities that demand strength for a long time (Tamara and Siti, 2017) Thus, resistance can be interpreted as the body's ability to overcome the workload in a relatively long time without causing significant fatigue. Endurance is one important element of physical condition, because it is the basis of elements from other physical conditions. Physiologically, endurance is related to the ability of the heart and respiratory organs. Respiratory-cardiovascular endurance refers to a person's ability to continue longlasting (sub-maximum) contractions using a number of muscle groups with a length of time and intensity that requires support from circulation and breathing (Santoso, 2016).

From the findings of research on aerobic endurance of volleyball players in SMAN 1 Lintau Buo Utara, the category of aerobic endurance of male volleyball players is only in sufficient classification and the aerobic endurance of female volleyball players is in the medium classification. This might be due to lack of training, facilities and infrastructure, trainer quality, programmed training, nutrition, and variations of training. Low aerobic endurance will certainly affect the achievements of male and female volleyball players in SMA Negeri 1 Lintau Buo Utara, because aerobic endurance possessed by low players means that in this case the physical fitness is lacking so that it cannot last long and can affect the tempo of the movement skills in competition such as fatigue, lack of enthusiasm, frequent technical errors. For this reason, efforts that can be made to improve aerobic endurance are in the form of jogging and jump rope training, such exercises if done for a long time will develop aerobic capacity.

\section{Eye-hand Coordination}

Coordination is the ability to complete motor tasks precisely and directedly determined by the process of controlling and regulating movements and cooperation in the central nervous system "(Syafruddin, 2011: 62). With that eye-hand coordination is one important element and is needed in every sporting skill. Coordination is an adjustment that affects a group of muscles and during a movement that gives an indication of various skills (Iskandar, 2014).

Coordination is the ability to control body movements. Someone is said to have good coordination if able to move easily and smoothly in a series of movements, the rhythm is well controlled and able to make efficient movements. Almost all movements performed by sports are constantly controlled and coordinated by the central nervous system (Juilta, et al. 2013). The level of coordination of a person can determine the mastery of a sports skill, moreover that skill is classified as mastering the technique of hitting skills as in the implementation of smashes and services in volleyball game.

Based on the results of data analysis, it can be concluded that the hand-eye coordination of male and female volleyball players at SMAN 1 Lintau Buo Utara is still low. Therefore, it must be improved by training the level of eye-hand coordination by providing eyehand coordination exercises such as throwing catches ball to the wall, and catch the ball while forward or back and various other variations of movement.

\section{CONCLUSIONS AND SUGGESTIONS}

Based on the table above, it can be concluded that the component of a good physical condition review in the volleyball players in SMAN 1 Lintau Buo Utara is agility, while the bad one is eye-hand coordination.

\section{REFERENCES}

[1] Arikunto, Suharsimi. 2010. Research Procedure. Jakarta: PT. Rineka Cipta

[2] Budhiarta, Made Danu.2010. The Influence of Plyomeyrik Training on Bench Skip Against the Explosion Power of Limbs in the Department of Social and Political Sciences, Undoksha FOK 
Undiksha. Journal of Health \& Sport. Vol: 1, No: 1.

[3] Judge, Wisdom. Contribution of Arm Explosion Power and Determination of Backward Strike Against Service Skills for Volleyball in High School Students 1 Banteng.Comptitor. Vol: 2 Years 4

[4] Irawadi, Hendri. 2013. Physical Conditions and Measurements. Padang: FIK UNP

[5] Iskandar.2014. Relationship of Mara-hand Coordination with Volleyball Service for Male Students of Penjaskes IKIP - PGRI Pontianak. Sports education journal. Vol: 3, No: 2

[6] Ismaryati. 2006. Sports Measurement Tests. Surakarta: Eleven March University Press

[7] Juita, et al. Contribution of Arm Muscle Explosion Power and Eye-Hand Coordination to Service Accuracy of Volleyball Students of Sport Coaching Education in Riau University. Journal of Primary Primary School Teacher Education Program and Faculty of Teacher Training and Education, University of Riau. Vol: 2, No: 2

[8] Marjana, Wayan, et al. 2014. The Effect of Shuttle Run Training on Speed and Agility. e-journal IKOR Ganesha Educational University Department of Sport Science. Vol: 1

[9] Regulation of the Minister of Education and Culture of the Republic of Indonesia Number 62 of 2014. About extracurricular activities in basic education and secondary education. Jakarta: Increased by the Legal Bureau and Organization of the Ministry of Education and Culture

[10] Ridwan, Mukhtar. 2016. Effect of Balance, Agility and Motivation to Exercise Against Passing Skills for Volleyball in SMA Negeri 1 Panggarangan, Lebak Regency. Multilateral Journal. Vol: 14, No: 1

[11] Santoso, Danang Ari. 2016. Analysis of the Physical Fitness Level of the Women's Volleyball Athlete at PGRI Banyuwangi University. Kejaora Journal. Vol: 1 No: 1

[12] Setiawan, Y., Sodikoen, I., \& Syahara, S. (2017). The Contribution of Leg Muscle Strength and Dynamic Balance Towards The Ability of Dollyo Chagi Kick.

[13] Siregar, Irwansyah. 2015. The Relationship between Muscle Power and Back Muscle Flexibility Against Service Ability in Volleyball Games. Journal of Community Service. Vol: 21 No: 79
[14] Sudijono. 2012. Introduction to Education Statistics. Jakarta: Rajawali Press.

[15] Syafruddin.2011. Sports Coaching Theory and Application in Sports Coaching. Part: UNP Press

[16] Tamara, Satria Alpra and Siti Nurrochmah. 2017. Physical Condisin Profile of Lung Heart Resilience Element Participants in the BallBasket and Volleyball Extracurricular Activities in SMA Negeri 1 Kepanjen Malang Regency. Journal of Physical Education. Vol: 1, No: 2

[17] Law of the Republic of Indonesia Number 3 of 2005 concerning the National Sports System. Jakarta: Reproduced by the Public Relations and Legal Bureau of the Ministry of Youth and Sports of the Republic of Indonesia. 